\title{
Itemizes East Java Heritage Tourism Nexus: In Consort of "Pentahelix" Method via Didactic Vicissitudes Adherence
}

\author{
Sultan Bagus Firmansyah \\ Applied English Language, Airlangga University, 60386, Indonesia \\ sultanveritas@gmail.com
}

\section{ABSTRACT}

As $21^{\text {st }}$ century and/ or urban spots skyrocketing nonstop, particularly at East Java, a bunch of anti-outmoded places' quantity exceeds both heritage and monumental tourism sites. Attempting archaic didactic principles in familiarizing pupils with heritage tourism equal nothing, nor is (using) printed book; nevertheless, a fine-tech focal notion shall be done. This research heads renewal worth noting idea, it's Pentahelix; the method coalesces Academician, Business, Community, Government, and Media abbr. ABCGM, thus, foregoing fifth stakeholders can emerge a distinct tactic of transferring heritage tourism science to students. It can by locating learners' interests via sophisticated 5.0 features e.g. Virtual Reality/VR, Augmented Reality/ AR, 3D Demo, etc. To do so, pupils' endeavour forecast is aimed at history-savvy, minifying heritage unawareness, and nurturing annals of historic sites. A resilient historic site encompasses Edu-tourism importance, by a view from within, this research has $\leq 38$ respondents (from 29 regencies and 8 cities in East Java province) whose essence about monumental tourism preservation weightiness.
\end{abstract}

ARTICLE HISTORY

Submitted:26.06.2021

Revised:27.06.2021

Accepted:08.07.2021

Online first:10.07.2021

\section{KEYWORDS}

Pentahelix, archaic didactic principles, Tourism, Heritage,

History-savvy 


\section{Introduction}

By the former minister of tourism of Indonesia then, issued as Republic of Indonesia Ministerial Act/ Law, No. 14, 2016, focusing on Sustainable Tourism Destinations' Guidelines, it stresses "Pentahelix" as a notion to empower tourism and convert it into the lesson; reespoused upon both Act/ Law, No. 5, 2017, concerning the Cultural Development Endeavor, and No. 11, 2010, regarding Cultural Heritage (Assistant Deputy of Cultural Tourism Development; Deputy for Industrial and Institutional Development, 2019). While Act/ Law, No. 4/ 1999, and No. 13/ 2018 by East Java province (Rencana Kerja Pemerintah Daerah (RKPD) Prov. Jatim, 2021) revealed, a huge amount of mismanaged tourism reported-archive, meantime, approximately East Java's 292 tourism villages are already done of being Community Based Tourism (CBT) per 2018 - 2021.

To signalize pupils for tangible heritage spots over 29 regencies and 8 cities in East Java, the normative endorsement format might less effective, but the distinct path is the opposite. Teachers have had imposed learners' aptitude through historical printed books and shall impact them gone bored, perhaps it does tiresome study-tone is. Integrating multisophisticated device programs (e.g. Apps, Demo, G Maps, etc.) can attract immense of historic lesson interests; That's a clue of Didactic Vicissitudes Adherence meant by.

In her research (Didactic Principles of University Information Educational Systems Designing, 2017, p. 1206), Mariya M. Gorovaya emphasized, traditional Didactic base executes teaching-learning-evaluating into educational dimension. But, "Didactic Vicissitudes" offers a miscellaneous study atmosphere; the innovation upbringing differentiation from the genuine ones; a FinTech becomes a vital part of this notion. Instead of printed books, and to learn the heritage tourism from history, students have to utilize modern devices via virtual tours i.e. Augmented Reality/ AR, Virtual Reality/VR, 3D Demo, etc. Subsequently, the device can portray neat and nice summarized heritage tourism around East Java, therein.

\section{Method}

More or less $\leq 38$ respondents have been gathered to enrich actual data/-fact, contrary, they aren't invariably students but, (such as) barista, travellers, visitors, and commoners. It's verbatim research by goes on to trivial matter. They frequently mourn the hardest of understanding heritage tourism through historical books (table 1.), especially to learners since such a "monotone" didactic approach has seen worthless. 
Table 1. Brief Assessment of Respondent's Interests in Learning Heritage Tourism

\begin{tabular}{|c|c|c|c|c|}
\hline Respondent & & $\begin{array}{cc}\text { Score } & \text { Media } \\
\text { Ages } & \\
\end{array}$ & & quency \\
\hline Amita (Kab. Kediri) & 10 & Socmed (Instagram) & $\sqrt{ }$ & 20 y.o \\
\hline Aldi Laksa (Kota Madiun) & $\leq 5$ & Book and Socmed & $\sqrt{ }$ & $21 \mathrm{y} . \mathrm{o}$ \\
\hline Yuli Rusdiana (Nganjuk) & 8 & Magazine and Report & $\sqrt{ }$ & 20 y.o \\
\hline Melinda (Bojonegoro) & 10 & Socmed and Demo & $\sqrt{ }$ & 20 y.o \\
\hline Galuh Arwi (Surabaya) & $\geq 10$ & Socmed and Visiting & $\sqrt{ }$ & 20 y.o \\
\hline Jasmine (Sidoarjo) & 10 & Direct/ -Visiting & $\sqrt{ }$ & 19 y.o \\
\hline Nur Lailiyah (Gresik) & 10 & Socmed & $\sqrt{ }$ & 22 y.o \\
\hline Galih Puji (Ponorogo) & 10 & Drect and Socmed & $\sqrt{ }$ & 20 y.o \\
\hline Arief Junyardi (Bangkalan) & 10 & YouTube and Demo & $\sqrt{ }$ & 19 у.о \\
\hline Refi Deo (Lamongan) & $\leq 6$ & Direct & $\sqrt{ }$ & 19 y.o \\
\hline Nanda (Kab. Mojokerto) & 10 & Visit and Socmed & $\sqrt{ }$ & 20 y.o \\
\hline Achmad Faris (Pasuruan) & $\geq 5$ & Study Tour/-Visit & $\sqrt{ }$ & 20 y.o \\
\hline Aditya W. (Probolinggo) & 10 & Socmed and Demo & $\sqrt{ }$ & 24 y.o \\
\hline [1]Total: $13 /$ & \multicolumn{2}{|c|}{${ }^{[2]}$ Interests Average: \pm 10} & ${ }^{[3]} F_{1}$ & es Ave \\
\hline
\end{tabular}

*) Assessment Value: Sufficient

*) Respondents have permitted to mention the name of theirs

Pupils' "normative" syllabi settled them into progress stagnancy, and it's ubiquitous. Nonetheless, well-modernized tourism education enthrals 5.0 growth of learning etiquette. First, Applefeld (2013) claims how Augmented Reality/ AR has potentially emerged as preeminent alternatives. In another case, information can be modified to specific needs and preferences (Hyman, 2013). AR shifts usual didactic to different ones. Second, Ankomah and Larson (2000) asserted, educational tourism is a program and, it related to activity whose aim to educate anyone with a particular area. Therefore, as foregoing both definitions will be installed, these: (i). Pentahelix, (ii). Didactic Vicissitudes, and (iii). East Java Tourism Nexus objectives can be accomplished.

"Heritage tourism intensity is highly rare, yes, rare to be visited, spotted, and interested but, it's capacity beyond important; it is legacy", said Handoko (17 y.o), the Barista worker. Per Ali Bakir et al. (2017, p. 245), in their "Cross-cultural Issues in Tourism and Hospitality" proceeding research mention, "In so doing, it enhances our knowledge and understanding of the whole tourism services related systems". Thus, the aim of "Edu-tourism" in a Pentahelix (fig. 1) is flexibly switchable into "educational excursion", and of course it would via 5.0 properties. 
Figure 1. Scope of Pentahelix's Method

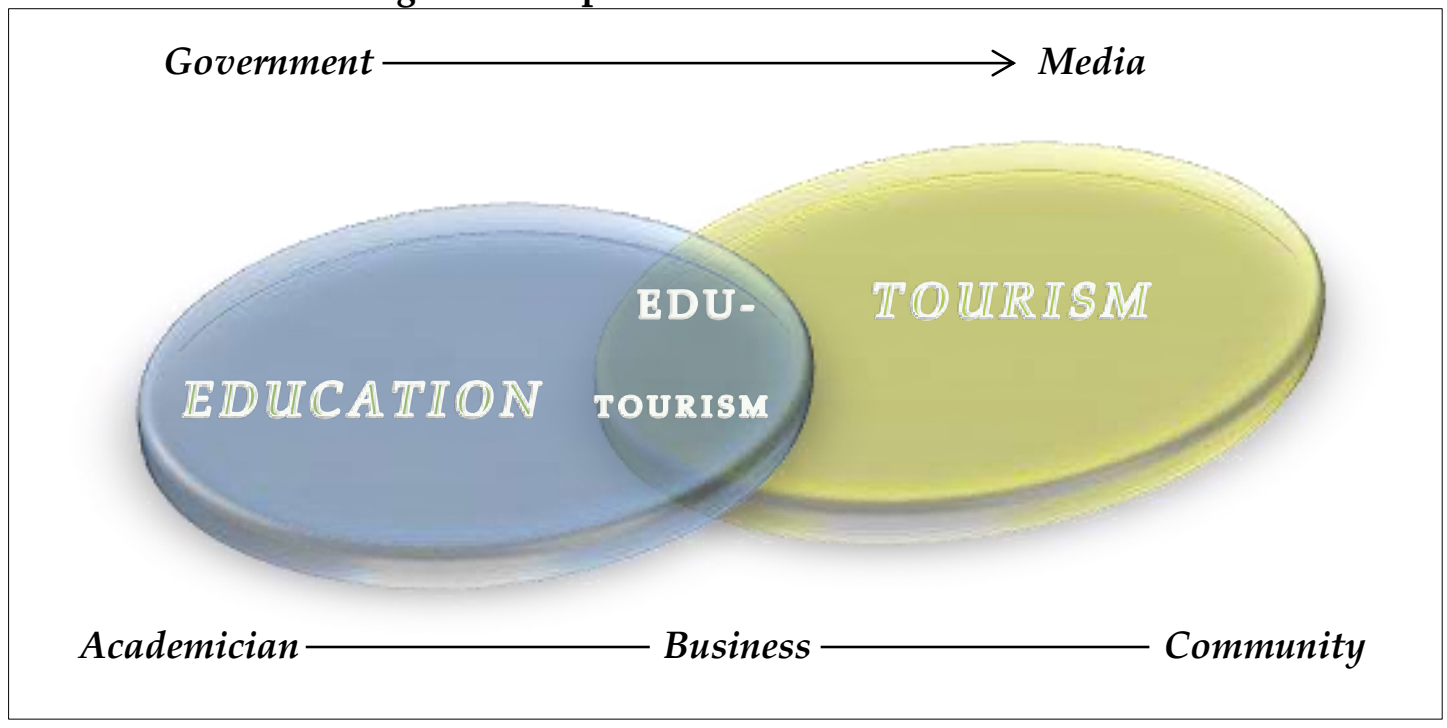

The diagrams above illustrate a role-play queue, which means the most top the vital ones, the lowest are the supporters. In Edu-tourism, the English Language can be immersed too (Huang, 2008), table 2. narrates what are the further needs:

Table 2. Model of English Language for Edu-Tourism Needs

\section{Dimension of English For the Edu-Tourism}

1. English for Food and Beverage Services

2. English for Air Flight Services

3. English for Hotel Services

4. English for Tour Managers and Guides

Hyung-ji Chang (2020) linking the previous "inserted" didactic course model with his Flipped Learning mode, which is performed 7-aspects of the diverse lesson, namely PARTNER: (i). Preparation, (ii). Assessment, (iii). Relevance, (iv). Team activity, (v). Nub lecture, (vi). Evaluation, and (vii). Reflection.

Heritage tourism conservation tries to care for the maintenance of the monuments, or in any similar of it (Pravin S, 2000). The narrower, cultural heritage is must be considered as a contemporary development asset (Monika, 2012). For the students, sometimes, historic printed books come to detail, enigmatic ${ }^{1}$, and esoteric ${ }^{2}$. Networking them into Visionaire unique

\footnotetext{
${ }^{1}$ Shows what is totally expert to figure out, similar with "difficult" thought

${ }^{2}$ Thing that it's understood by minority
} 
approach relates to what "Nexus" meant for (as it's popped up for the title). A pair of 5.0 installations (table. 3) to Didactic Principles express its vicissitudes are.

Table 3. Aim of Didactic Vicissitudes via 5.0 FinTech

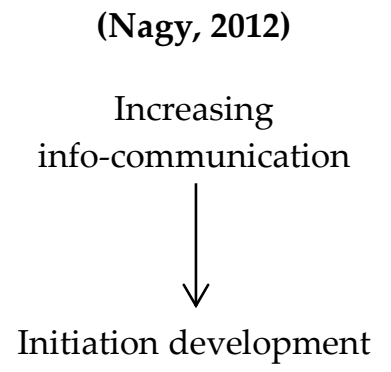

(Stoep, 2007)

Recognizing benefits of Tourism

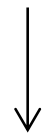

Develop historic resources
(Koca \& Yildirim, 2018)

Gaining momentum development

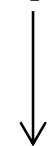

Existing tourism potential
This research

Utilize 5.0 FinTech for edutourism

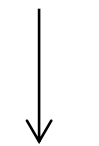

Encompass East Java heritage tourism nexus

\section{Result and Discussion}

Plenty of studies have shown that profound FinTech uses are handy; per Chiara Garau (2014) expressed, smartphones or AR can develop the development of cultural heritage within the urban level. This was almost close with Liarokapis et al. (2006) argued that AR services "urban navigation" of the city; so that it can be helpful for the learners too.

Numerous solemn words focused on sustaining heritage tourism, besides Pentahelix, the intact output and strategy of this research adopt Warapon's (2011), Method of Multi-criteria Decision Making or MCDM, are the guidance to convert the data-especially on transforming the old-time Didactic Principles to distribute knowledge shares of heritage tourism importance around 29-regencies and 8-cities at East Java province via decent 5.0 equipment, and that it's AR.

Information and Communication Technologies (ICT) energizes the theoretical framework for tourism studies (Caldevilla-Dominguez, Martinez-Sala, \& Barrientos-Baez, 2021). Likewise, it can locate the Digital Literacy (DL) study tone-that's one integrated frame/-idea as Viktoriia Prima (2020) had, she, donates the needs attribute inside of AR: (i). Electronic or audiovisual guide, (ii). Geographic information, (iii). History information, (iv). Culture information, (v). Attraction, (vi). Types of habitat, (vii). Food, (viii). Transport, and (ix). Entertainment.

In his capacity, Dario Cianciarulo (2015) be critical of AR in fact, drawing the information (including VR and 3D Demo experience) to the real environment; and the didactic reconstruction etiquette element for the learners (fig. 2) refers to the anonymity of simplicity. 
Figure 2. The set of Didactic Reconstruction Model

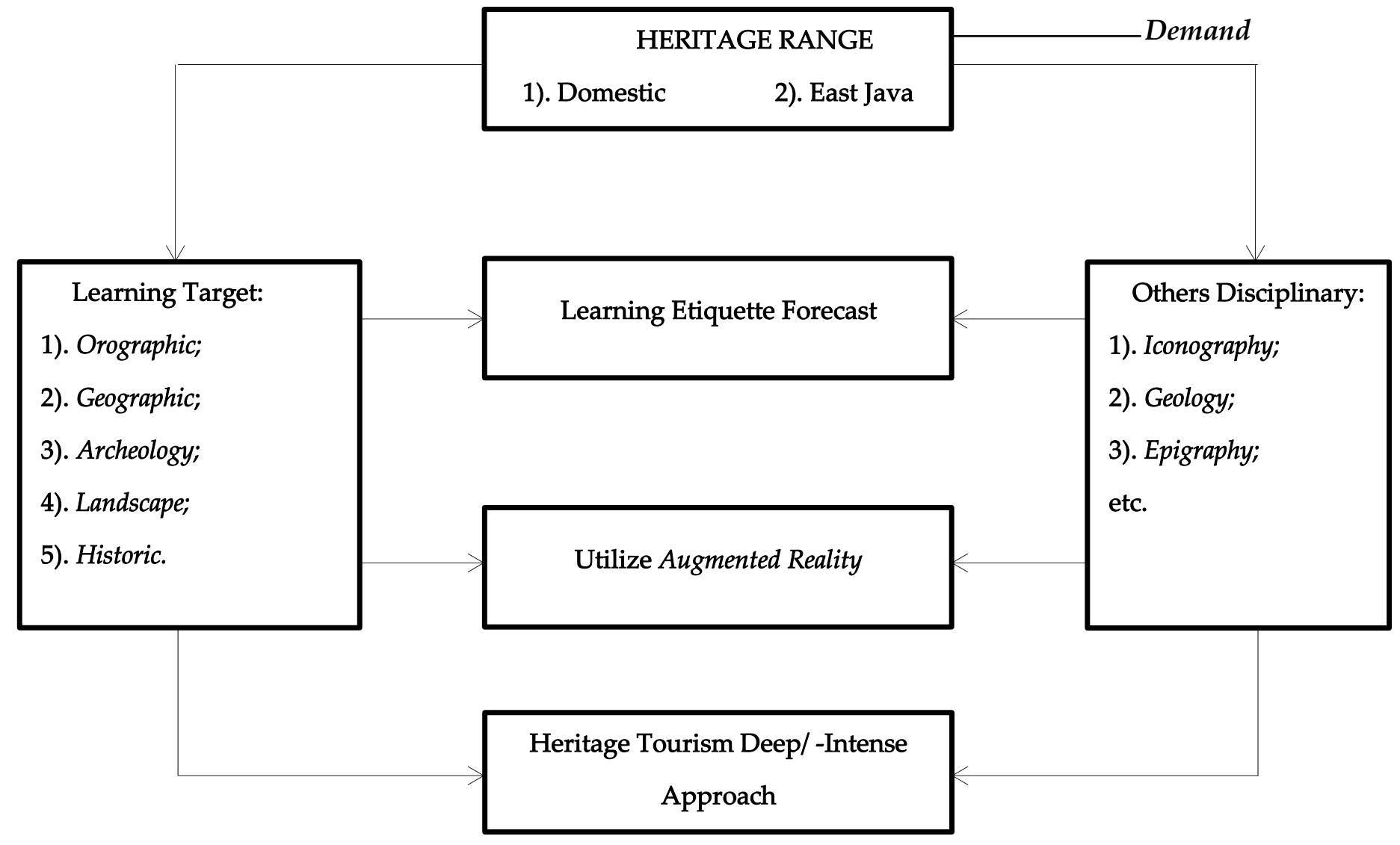

*) Data source: Stefano Del Lungo, et al. (2015). Landscape and cultural heritage: best practices for planning and local development: an example from Southern Italy. Procedia. Pp. 95-102. ELSEVIER.

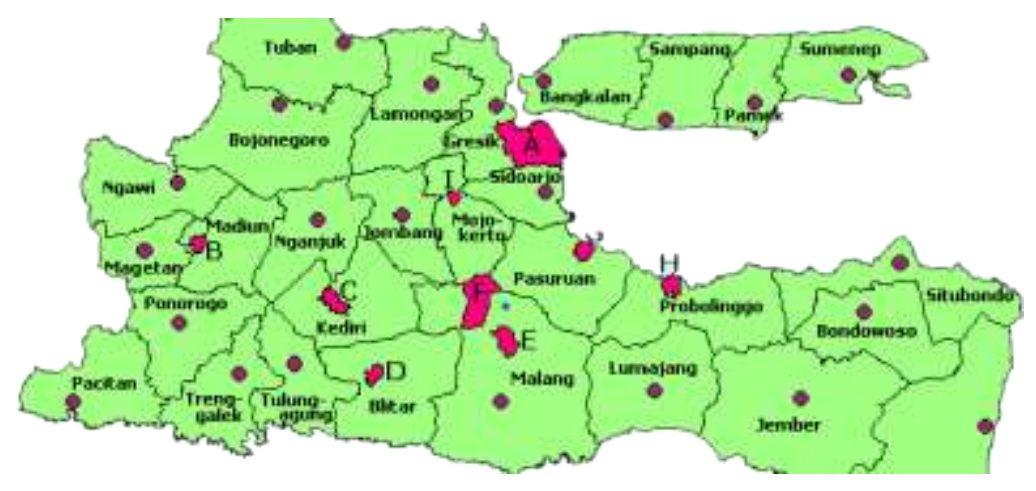

Map 1. 29-Regencies \& 8-Cities at East Java through a map 
On p 308, Zoltan Budjoso et al. (2015) conveyed that, in the narrower cycle, cultural heritage can mash-up: (i). Fine arts, (ii). Music, (iii). Dance, and (iv). Literature knowledge.

Since there 29-regencies and 8-cities around East Java province, means the potential of cultural/ -heritage is massive; AR can spot and virtualize them; fig.3 represents how AR's works by specifying heritage tourism explanation into various disciplinarians:

- Orographic;

- Geographic;

- Archeology;

- Historic;

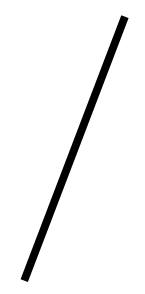

- Iconography;

- Geology;

- Epigraphy;

- etc.

\section{Conclusion}

Heritage resources are increasingly being seen as important attractions (Maria D. Alvarez., 2016). AR simulates the physical sign upon the heritage tourism sites; it can enhance environmental performance and "introduction" (Leslie, 2006). Quintessentially, the way how it grows (fig.3) is:

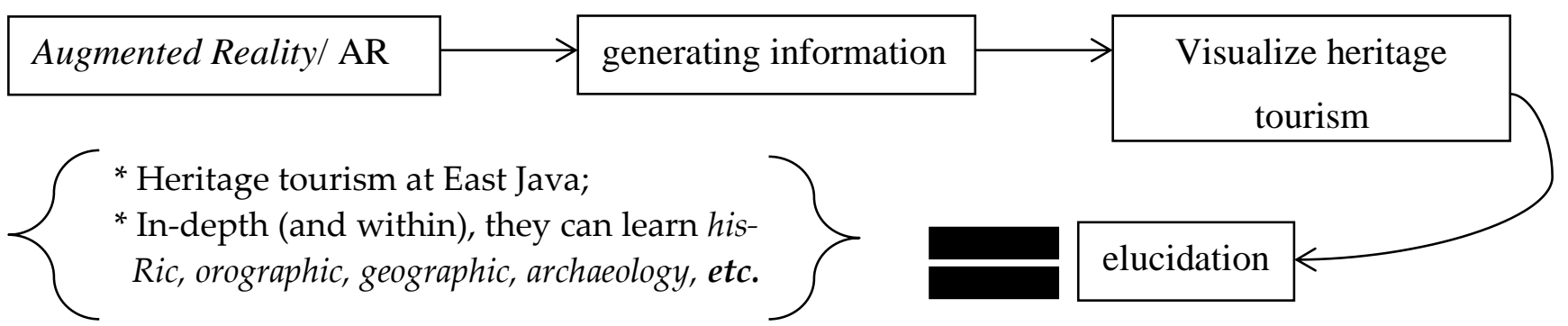

During the current AD 21's, East Java heritage sites have publicly rarely known; numerous modern places been banished their reputation, they have had to entrust millennials ${ }^{3}$. At glance, East Java heritage tourism can be displayed and, may broaden towards AR; it can embark both learners and commoners' enthusiasm to spot the fraught of sites by map-once users click the "spotted" regency and/ or city virtualized inside of AR (map. 2), the machine will virtually pilot them sign-seeing on to the place he'd choose 


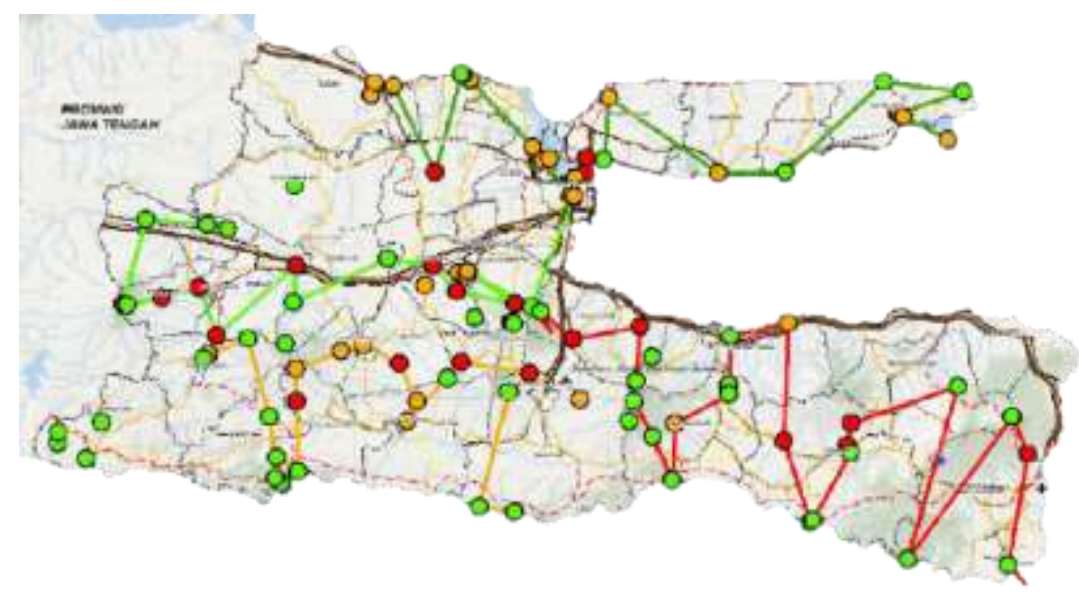

Map 2. Illustration of Detected "Heritage Tourism" inside of AR

*) Indicator(s):
Absence
Less
Presence

Those three colours indicate the existence of heritage tourism in a regency and/ or city and, whether it's preserved or the opposite. In-depth, both erudite and commoner can investigate how is the serialization ${ }^{4}$ there.

- First, red-lighted circle signifies the heritage tourism in the regency and/ or city is neglected;

- Second, an orange lighted circle indicates less intensity of heritage tourism in the regency and/ or city;

- Last, a circled green site equal the existence of heritage tourism in the regency and/ or city.

Table 4. Spatial Distribution of Heritage Tourism Presence at East Java

\section{Regency}

*) Total: 29

Kabupaten Madiun

Kabupaten Bangkalan

Kabupaten Banyuwangi

Kabupaten Blitar

Kabupaten Bojonegoro

Kabupaten Bondowoso

Kabupaten Gresik
*)Total: 8

Kota Batu

Kota Blitar

Kota Kediri

Kota Madiun

Kota Malang

Kota Mojokerto

Kota Probolinggo
Sampling

Sr Ms If

$++\quad+\quad-$

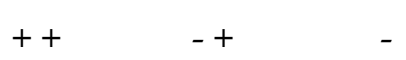

$+\quad++\quad-$

$\begin{array}{lll}+- & +\end{array}$

$++\quad--\quad+$

$\begin{array}{lll}- & ++\end{array}$

\footnotetext{
${ }^{4}$ That term is borrowed Ake Nilsson's (2018) mine, by his research: Impact of Cultural Heritage on Tourists. The Heritahization Process
} 


\begin{tabular}{lcccc}
\hline Kabupaten Jember & Kota Surabaya & ++ & - & - \\
Kabupaten Jombang & + & - & - \\
Kabupaten Kediri & + & - & - \\
Kabupaten Lamongan & + & - & + \\
Kabupaten Lumajang & - & + & + \\
Kabupaten Magetan & + & - & - \\
Kabupaten Malang & + & - & - \\
Kabupaten Mojokerto & - & + & + \\
Kabupaten Nganjuk & - & + & + \\
Kabupaten Ngawi & - & + & + \\
Kabupaten Pacitan & + & - & + \\
Kabupaten Pamekasan & - & + & - \\
Kabupaten Pasuruan & - & + & - \\
Kabupaten Ponorogo & - & + & - \\
Kabupaten Probolinggo & - & + & - \\
Kabupaten Sampang & - & + & + \\
Kabupaten Sidoarjo & - & + & + \\
Kabupaten Situbondo & - & + & + \\
Kabupaten Sumenep & - & + & + \\
Kabupaten Trenggalek & - & + & + \\
Kabupaten Tuban & - & + & + \\
Kabupaten & + & - & - \\
Tulungagung & - & + & + \\
\hline
\end{tabular}

\section{Notes: Indicator " $\mathrm{A}$ "}

(1). $+=$ Presence, (2). - = Absence, (3). Sr = Superior, (4). Ms = Mainstream,

(5). If = Infamous.

\section{Indicator "B"}

*) "Sr" regency/-cities categorized as excellent heritage tourism in the most;

*) "Ms" regency/-cities noted as middle heritage tourism eminency;

*) "I $f^{\prime \prime}$ regency/-cities means heritage tourism must be promoted to cliques; 


\section{Author's declaration}

\section{Authors' contributions and responsibilities}

$\checkmark$ The authors made substantial contributions to the conception and design of the study.

$\checkmark$ The authors took responsibility for data analysis, interpretation and discussion of results.

$\sqrt{ }$ The authors read and approved the final manuscript.

\section{Availability of data and materials}

$\sqrt{ }$ All data are available from the authors.

\section{Competing interests}

$\sqrt{ }$ The authors declare no competing interest. 


\section{References}

[1] Ali Bakir, e. a. (2017). Cross-Cultural Issues in Tourism and Hospitality. Tourism and Hospitality Research. 17(3), p. 245. England, UK.: Sage.

[2] Ankomah, P. \&. (2000). Education Tourism: A Strategy to Strategy to Sustainable Tourism Development in Sub-Saharan Africa. DPMN Bulletin, 7(1), 19-24.

[3] Applefeld, N. (2013). Four Ways to Reinvent Retail Marketing through Augmented Reality. Retrieved from Spin Sucks: http://spinsucks.com/marketing/four-ways-to-reinventretail-marketing-throughaugmented-reality/

[4] Assistant Deputy of Cultural Tourism Development; Deputy for Industrial and Institutional Development. (2019). Pedoman Pengembangan Wisata Sejarah Dan Warisan Budaya. Jakarta Selatan: Ministry of the Tourism Republic of Indonesia.

[5] Caldevilla-Dominguez, D., Martinez-Sala, A., \& Barrientos-Baez, A. (2021). Tourism and ICT. Bibliometric Study on Digital Literacy in Higher Education. Education Sciences, 11, $1-17$.

[6] Chang, H.-J. (2020). The Flipped Classroom Approach for Tourism English Learners. English Teaching, 75(3), 96.

[7] Cianciarulo, D. (2015). From local traditions to "augmented reality". The MUVIG Museum of Viggiano (Italy). Procedia: Social and Behavioral Sciences, 138-143.

[8] Garau, C. (2014). From Territory to Smartphone: Smart Fruition of Cultural Heritage for Dynamic Tourism Development. Planning Practice and Research, 29(3), 238-255.

[9] Huang, C. (2008). English Curriculum Planning for Hospitality. Proceedings of 2008 International Conference of Applied Foreign Languages, 138-140.

[10] Hyman, P. (2013). Augmented-Reality Glasses Bring Cloud Security Into Sharp Focus. Communications of the ACM, 56(6), 18-20.

[11] Koca, N., \& Yildirim, R. (2018, April 4). Relationship between Geography-Tourism and Tourism's Effects According to High School Students. Review of International Geographical Education Online (RIGEO), 8(1), 26-52.

[12] Leslie, M. S. (2006). International Cultural Tourism: Management, Implications, and Cases. Oxford: ELSEVIER.

[13] Liarokapis, F. B.-O. (2006). Exploring urban environments using virtual and augmented reality. Journal of Virtual Reality and Broadcasting, 3(5), 1-13.

[14] Maria D. Alvarez., F. M. (Ed.). (2016). Heritage Tourism Destinations. Wallingford, Oxfordshire, UK: CABI. 
[15] Mariya M. Gorovay, (. a. (2017). Didactic Principles of University Information Educational Systems Designing. Eurasian Journal of Analytical Chemistry, 12(7b), 1206.

[16] Monika, M.-K. (2012). Cultural, Economic and social sustainability of heritage tourism: Issues and challenges, Economic and Environmental Studies (E\&ES). Economic and Environmental Studies, 12(2), 113-133.

[17] Nagy, K. (2012). Heritage Tourism, Thematic Routes and Possibilities for Innovation. Clubs of Economics in Miskold Journal of Economic Literature (JEL), 8(1), 46-53.

[18] Nilsson, P. A. (2018, March). Impact of Cultural Heritage on Tourists. The Heritagization Process. Athens Journal of Tourism, 5(1), 35-54.

[19] Pravin S, e. a. (2000). Sustainable Heritage Tourism: Framework, Perspective and Prospect. National Geographic Journal of India, 46(1-2), 141-158.

[20] Prima, V. (2020). Terminological Field <Tourism $>$ in English Tourism Discourse. Language Teaching Research Quarterly, 14, 69-79.

[21] Provinsi Jawa Timur. (2021). Rencana Kerja Pemerintah Daerah (RKPD) Prov. Jatim. Pemprov Jatim.

[22] Stefano Del Lungo, e. a. (2015). Landscape and cultural heritage: best practices for planning and local development: an example from Southern Italy. Procedia: Social and Behavioral Sciences, 95-102.

[23] Stoep, G. V. (2007). Consideration of Historical Authenticity in Heritage Tourism Planning and Development. Proceeding of the 2007 Northeastern Recreation Research Symposium (pp. 292-298). Lansing, MI: Michigan State University.

[24] Warapon Ngamsomsuke, e. a. (2011). Sustainable Cultural Heritage Tourism Indicators. International Conference on Social Science and Humanity, 5, 516-519.

[25] Zoltan Budjoso, e. a. (2015). Basis of her itemization and cultural tourism development. Procedia: Social and Behavioral Sciences, 307-315. 